\begin{tabular}{l} 
RCCS \\
\hline Annual Review
\end{tabular}

\section{RCCS Annual Review}

A selection from the Portuguese journal Revista Crítica de Ciências Sociais

$1 \mid 2009$

Issue no. 1

\title{
History, Memory and Forgetting: Political Implications
}

\section{Maria Paula Nascimento Araújo and Myrian Sepúlveda dos Santos}

Translator: Sheena Caldwell

\section{(2) OpenEdition}

\section{Journals}

Electronic version

URL: https://journals.openedition.org/rccsar/157

DOI: $10.4000 /$ rccsar. 157

ISSN: 1647-3175

Publisher

Centro de Estudos Sociais da Universidade de Coimbra

\section{ELECTRONIC REFERENCE}

Maria Paula Nascimento Araújo and Myrian Sepúlveda dos Santos, “History, Memory and Forgetting: Political Implications", RCCS Annual Review [Online], 1 | 2009, Online since 01 September 2009, connection on 21 September 2021. URL: http:// journals.openedition.org/rccsar/157 ; DOI: https://doi.org/10.4000/rccsar.157 
Maria Paula Nascimento Araújo

Rio de Janeiro Federal University, Brazil

\section{Myrian Sepúlveda dos Santos}

Rio de Janeiro State University, Brazil

\section{History, Memory and Forgetting: Political Implications*}

Researchers have raised questions about recovering traumatic situations such as the Holocaust, the bombing of Hiroshima, the Vietnam war or the fratricidal massacres in Yugoslavia. Although some classic studies have identified important aspects relating to history and memory, there are several ways of dealing with the past, all of which involve interests, power and exclusion. The politics of just memory with regard to crimes committed in the past, a debate in which various academic areas as well as society in general have been involved, depends on processes of selection and also on elements which extend beyond the scope of human reason. It is necessary to find a balance between an obsession with the past and attempts to impose forgetting. Our aim, therefore, is to extend our understanding of history, memory and forgetting, emphasizing their limits as well as their ethical and moral implications.

Keywords: History; memory; forgetting; politics of memory; trauma.

\section{Introduction}

The aim of this article is to investigate the impasses between memory and forgetting that are present in debates on the preservation and dissemination of archives associated with conflicts, wars and periods of political oppression. The debate on justice for crimes committed in the past, in which various academic areas as well as society in general have been involved, is greatly aided by documents and testimonies, although it is not solely dependent on them. However, societies do not always choose to remember. Our aim, clearly, is not to devote this entire discussion to remembering and forgetting, but rather to extend our understanding of these terms, and this also implies establishing their limits.

The first part of this article is based on the work of sociologists, historians and philosophers such as Maurice Halbwachs, Pierre Nora and Paul Ricoeur on collective memory. Historical narratives that preside over the organisation of archives, collections and museums remind us of what has passed or, in other words, what is no longer present amongst us. However, they do not reveal an absolute truth; instead they lead us to the process of constructing collections on the basis of conflicting interests. Memory operates as a selective process and may become a political weapon for the victims of war and genocide when forgetting has established its hegemony.

\footnotetext{
${ }^{*}$ Article published in RCCS 79 (December 2007).
} 
The second part of this article deals with cases in which more than one selective process is involved in what is to be remembered. Authors such as Georges Bataille and Max Scheler present situations in which individuals and communities may be incapable of conveying what they have learned from experience and pain when looking back at the past. Memory does not merely obey reason, since it is also related to inherited traditions which form part of our identity and which we cannot control and, in addition, to deep feelings such as love, hate, humiliation, pain and resentment, which emerge independently of our will.

As a result of these challenges, the third part of this article presents various historical situations in which alternatives are being constructed with the aim of overcoming the distance between the past and the present and to establish an agenda in which remembering is linked to the possibility of forgetting.

\section{The selective process of memory}

Maurice Halbwachs was the first sociologist to redeem the topic of memory for the field of social interaction. ${ }^{1}$ Rejecting the idea current at the time that memory was the result of the impression of real events on the human mind, he established the thesis that people weave their memories together on the basis of the various forms of interaction that they engage in with other individuals. Therefore, certain memories are repeated within the family, others among workers in a factory and so on. As individuals do not belong only to one group but are involved in multiple social relationships, the individual differences in each memory express the results of each person's trajectory throughout their lives. Individual memory only reveals the complexities of the social interrelations experienced by each person.

The general merit of Halbwachs' work, therefore, was to show that individual memory cannot be separated from collective memories. The individual alone does not have control over recovering the past. Memory is formed by individuals interacting with each other and by social groups, and individual memories are the result of this process. Even though the individual may think that their memory is strictly personal, as it recalls events in which only they were involved or facts and objects which only they witnessed and experienced, it is, in fact, collective since the individual, even if alone, is the product of social interactions and

\footnotetext{
${ }^{1}$ Maurice Halbwachs established the main theoretical arguments in support of the collective nature of memory in two books that are nowadays considered standard reference works on the subject, Les cadres sociaux de la mémoire (1925) and La mémoire collective, the latter published posthumously (1950).
} 
views the world through collective constructs such as language. If lost in the same desert, two individuals from different cultural traditions will have different memories, descriptions and feelings associated with their experiences. These will not, strictly speaking, be individual since, as Halbwachs affirms, the individual is never alone.

In making memory the subject of the social sciences Halbwachs reiterates Durkheim's argument on the predominance of collective over individual consciousness. This emphasis by Halbwachs on collective representations has been theoretically counterbalanced by others who have investigated the involvement of social agents in interactive processes. Memory, tradition and history are conceived by some authors to be collective representations actively formed by social actors. The collection of articles compiled by David Middleton and Derek Edwards consolidates the interactionist approach to studies on collective memory (Middleton and Edwards, 1990). Yet, despite the differences, both Halbwachs's study of the social frameworks for memory and the interactionist approaches to collective memory show that neither historical truth nor spontaneous memory really exist.

Aware of these concerns, in the 1980s Nora edited an anthology of articles in which the authors explored "places of memory" in France or, in other words, symbolic places made by and making the French nation. The objects of study were not documentary sources or individual memories but evidence from past eras, including the founding of museums, archives, cemeteries, celebrations, collections and so on. Also relevant for the debate on collective memory was the distinction made by Nora between history and memory (Nora, 1984). In his introduction to the anthology, nowadays considered a standard reference work for studies in this area, Nora contrasts different approaches to the past. In his opinion, history corresponds to a modern acceleration of time, meaning that events are perceived as ephemeral, transitory and belonging to a homogenous time. He points out the limits of this historiography, which he describes as a logical and linear narrative, devoid of any content relating to the past. In contrast to history, collective memories are linked to ongoing movements and recollections transmitted from one generation to another. Nevertheless, they also have their limitations in terms of understanding the past, since individuals are not aware that their own perceptions transform the past. Individual or collective memory is vulnerable to manipulation (Nora, 1984; Davis and Starn, 1989) and therefore both history and memory are limited in their access to the past. 
In the distinction he makes between history and memory, Nora contextualises the different ways of looking at the past. He shows that, with modernity, perceptions of time and historical narratives follow the processes of time acceleration. Walter Benjamin, in his reflections on history, had already pointed out the limits of the historical approach which listed facts and events over homogenous time. Benjamin understood that the transmission of collective representations from individual to individual over time and space would become increasingly sparse and discontinuous (Benjamin, 1968). Another important author in terms of contextualizing historical narratives was the German historian Reinhart Koselleck. In his view, modernity is differentiated by the concept of the "new," which makes each moment unique and independent in relation to those which preceded it. The modern world is distinguished from the old because it is full of singular characteristics and is always open to the possibility of the future. This "time future," independent of everyday experience constructed over centuries, entails a break between the present and the past and banishes everything that has gone before it (Koselleck, 1985).

The belief in this hiatus between past and present and in the ongoing reconstruction of the past by the present is taken to its extreme by scholars exploring the concept of detraditionalisation. Authors such as Anthony Giddens (1990), Ulrich Beck et al. (1994) and Scott Lash (1998) argue that contemporary individuals possess great autonomy in relation to traditions, being detached and free to engage in new experiences. For them, contemporary societies are characterised by an accelerated pace of change, and the uniqueness of individuals is defined by their distance from collective past experiences. In contrast to Benjamin's pessimism, they believe that the more unstable and shifting social interactions are, the more important individual actions or, in other words, their capacity for choice and decision-making, become. In this context, historical narratives reflect an ongoing process of selection and reconstruction of traces of the past. ${ }^{2}$ Therefore, for these authors both history and memory deal with the discontinuity of modern time. Obviously there are still authors who believe in communication between past and present. The French philosopher Paul Ricœur was able not only to contextualise but also to skilfully interweave memory, history and forgetting. In his view, memory is an ongoing task that is always able to superimpose itself on pre-established structural processes (Ricœur, 2000).

\footnotetext{
${ }^{2}$ For a critique of detraditionalisation, see Santos, 1998.
} 
Our aim in this article is to show that there is a significant diversity of approaches to the past, almost all of which are permeated by tensions, conflicts and disputes. Memory, history and forgetting are necessary experiences which neither blend nor complement one another. Nowadays we find ourselves far removed from both the notion of history as a faithful record of the past and the reduction of memory to a kind of selective reconstruction of the past. Therefore, the fundamental step that must be taken is to understand that there is nothing natural in the reconstruction of the past.

The building up of archives, the classification of data and the organisation of events and celebrations are activities involving memory that play an essential role in the society in which we live. At any given time there is always an ongoing and significant political struggle associated with the creation and preservation of archives relating to periods of domination and violence in which human rights were abused. Throughout the $20^{\text {th }}$ century, the major demand of the victims of totalitarian and repressive governments found expression in movements to reclaim memory. Archives, artefacts and accounts of the past have been used as proof of a past that was deliberately forgotten in official versions of history, in an attempt to summon up everything that had been left in the limbo of history. Memory is therefore associated with those who wield power, since they decide which narratives should be remembered, preserved and disseminated.

In Latin America in the 1980s, military dictatorships were succeeded by democratic governments. In various countries legislation was introduced to provide for amnesties and pardons, enabling former opponents of the regime to be reintegrated, but at the same time preventing the trial of those who had been responsible for torture and other barbaric crimes. It is only in recent years that the pacts for pardon and forgetting have begun to be reviewed. In 2006, for the first time in Brazil, victims of kidnapping and torture under the military regime, whose lives had been brutally maimed, questioned the Amnesty Law that had been passed in $1979 .^{3}$ In Argentina, it is only in recent years that the so-called pardon laws have been questioned, and the courts have begun to review the crimes committed by

\footnotetext{
${ }^{3}$ The couple César Teles and Maria Amélia Teles, the sister of the latter, Criméia Almeida, and their two children, Janaína and Édson, began legal proceedings for moral and physical damages against an agent of the security forces in the 1970s, Carlos Alberto Brilhante Ustra.
} 
state employees associated with the military dictatorship. ${ }^{4}$ This has also happened in Uruguay and Chile. ${ }^{5}$

The various debates on truth and reconciliation in post-apartheid South Africa can also be understood as the result of a tenuous political agreement that is seeking to establish itself. The power contained in memories is so strong and complex that even the opposition, when it comes into power, cannot always encourage remembrances of the past that have been repressed. In the midst of the hatred and resentment that accumulated over many generations, what can be remembered? As tools of power, memory and forgetting have been used by various governments, both totalitarian and democratic, in order to secure political control over opposing forces. Forgetting has therefore also served as a political strategy used by democratic governments at particular moments. The previous examples are important because they show us that the associations between memory, autonomy and liberty, on the one hand, and forgetting and authoritarianism on the other hand, cannot be generalised.

The behaviour of the United States during the Vietnam War has not yet been properly and publicly debated in world forums, and it may be said that there is a lot to be remembered. The autobiography of Robert McNamara, the Secretary of Defense at the time, (2006), makes it clear that the many mistakes that were made have still not been properly judged. Those who supported the decisions to carry out a devastating massacre of Vietnamese civilians using napalm, toxic gases and bombing on a massive scale are still close to power. The moral blindness that still prevails today over Vietnam may be associated, on the one hand, with the continuity of the power of the United States in international affairs and, on the other hand, the inability of American society to distance itself from the crimes that have been committed. Archives and evidence are therefore undeniably important to the various opposing forces, and their political implications are significant in political disputes.

\footnotetext{
${ }^{4}$ Despite the strong movement of the "Mothers of the Plaza de Mayo", it was only in 2005 that Argentina revoked the Full Stop and Due Obedience Laws, also known as the pardon laws, which were blocking proceedings against those responsible for violating human rights. In 2006, the courts ruled that the pardon granted to former president Jorge Rafael Videla was unconstitutional. In the same year, former policeman Miguel Etchecolatz, aged 77, was sentenced to life imprisonment for crimes he had committed during the military dictatorship.

${ }^{5}$ In Uruguay, it was only in 2006, 21 years after the re-establishment of democracy, that the Public Prosecutor's Office requested proceedings to be initiated against soldiers and policemen responsible for crimes committed during the military dictatorship.
} 


\section{Facing the impossibility of remembering the past}

As initially stated, not everything that relates to the past is the object of present-day negotiation. The latest historiographical approaches have made the search for the past more complex than just the interplay of present-day interests. Authors such as Hayden White, in abolishing the search for an original, non-linguistic presence, reduce all approaches to attempts at interpretation that are restricted to the domain of language. ${ }^{6}$ This not only relativises narratives concerning the nature of an event, but also their political implications. One of the characteristics of contemporary historiography is the systematic revision of political conflicts in the modern era. In France, in addition to revising major events associated with the French Revolution, the legacy of the Vichy government is constantly being reinterpreted.

Some researchers also study memory in situations involving extreme aggression and violence. In this case, the inability of the victims to respond has been observed. Incapable of understanding the experiences they have lived through or of ascribing meaning to them, they become unable to use their memories selectively. Memory therefore cannot be reduced to a political tool; it extends beyond attempts to control it.

Attempts to recover traumatic situations such as those which took place during the Holocaust, the bombing of Hiroshima, the Vietnam war, or the fratricidal massacres in Yugoslavia have had the disturbing effect of draining these catastrophic events of the sense of tragedy they contained in the past. In the words of Georges Bataille, revealing the effects of the Hiroshima bombing became the opposite of revealing the facts (Bataille, 1995: 228229). That is to say, human representation of this catastrophe is not capable of accurately conveying the dimensions of the event and, instead, has the perverse effect of making banal something that is not so. In his view, as there are no words to describe the horror, the feeling of horror cannot be the starting point for attempts to describe this horror (ibidem). In providing an explanation of what has happened, the history that is recounted serves to justify unjustifiable violence and banish it from the collective imagination.

The possibility of representing reality is always a challenge. We may understand that there are no words to describe horror and that those who try to explain it end up by eliminating any possibility of facing or repairing the tragedy. Individuals find refuge in action, but do not always resolve problems related to violence and suffering, which are basic

\footnotetext{
${ }^{6}$ See White (1987), amongst others.
} 
components of human life. Researchers in various academic areas have been involved in studying the possibilities of reconstructing and explaining trauma.

Freud and Lacan have both shown in their own way that individuals do not have full control over their memories; they may return to them repeatedly without any desire on their part for this to happen, or they may disappear without the option of recall. For Freud, trauma is a consequence either of the devastating nature of an event or the psychic apparatus of the individual, which may not be prepared to respond to certain stimuli (Freud, 1955). When a particularly powerful stimulus acts on us, we may not be capable of responding to it. It breaks down our protective barriers to become part of our actual being and we are not able to defend ourselves against it. Our self-awareness fails. This explains the nightmares that repeatedly return, leaving individuals drained and unable to defend themselves. Past aggression returns in flashbacks, nightmares and other similar phenomena; it is the cause of certain symptoms, namely repetitive actions that aim to reduce the stress caused by the initial aggression.

In addition, the works of Nietzsche and Scheler help us to understand attitudes that overstep every moral limit that can be expected of human beings. Memory and forgetting also involve ethical and moral issues. Scheler, in his study on resentment, indicates how profound experiences related to suffering and humiliation can lead to a highly contagious feeling of vengeance and rancour (Scheler and Frings, 1994). In relating a traumatic experience to the identity of its subject, we may see that his attitude towards the past does not revolve solely around the knowledge of what he has left behind. Memory cannot be considered only as a reconstructed past. It may make the individual relive an experience and evoke new desires and emotions that may be extremely negative and self-destructive. Returning to the past may include the possibility of understanding, but it equally revives feelings that had previously been repressed. Even if representation is possible, we must enquire whether it is desirable, and if it is possible to integrate the trauma into our lives in a connected rather than pathological manner.

How do we respond, for example, to the issue raised by Taussig when he denounces the brutal decimation of the American Indians by the Spanish following their arrival in America? This anthropologist correctly argues that the conquest had already taken place and did not require such violence (Taussig, 1986). How are we to understand the Holocaust? How do we explain the massacre of the Tutsis in Rwanda? What can be said about the attitude of the 
Serbs in Kosovo? The more historians search for explanations for barbarities that have been committed, the more these excesses seem to remain beyond our logical and rational comprehension.

Some researchers believe that in cases of extreme violence there may be a direct relationship between event and representation. Like Bataille, Friedländer also argues that extreme violence has its own unique characteristics. The extermination of the Jews cannot be the object of theoretical discussion; it was a unique event and needs to be recorded as such. Since recollection of the traumatic event is, in most cases, extremely faithful and rigorous in its use of detail, it offers direct access to the real. Therefore, Friedländer believes that the Shoah, due to its excess, can be conveyed without distortion or banality. The extreme violence of the Holocaust has enabled historians to reorganise their understanding of the real. According to the author, since excess is beyond the individual's imaginative and representational capabilities, since it has no limits and is beyond representation, it speaks for itself (Friedländer, 1992). What the individual describes is not a construction of an event experienced in the past, but the event itself. Representation of the real without mediation is present in the testimony of traumatic situations. The evidence of the "present" is possible because awareness has been deactivated.

Archives, testimonies, statements and records are brought to light with the aim of conveying to future generations the absurdity of unnecessary violence. The Yad Vashem archives and memorial in Jerusalem contains the largest amount of information on the Holocaust in the world, and nowadays plays an important political role in denouncing and condemning those involved in the Hitler regime. Various other archives have a similar role. The International Rehabilitation Council for Torture Victims in Copenhagen also houses an important collection of statements and information on human rights violations that have occurred in more recent wars, such as those in Bosnia, Afghanistan and Iraq. Organisations are founded to fight against the arbitrariness of oblivion by recovering names and restoring the facts that can still be remembered. The role of these archives is not to explain what cannot be explained, but to keep alive the memory of what cannot be repeated.

We may therefore arrive at the conclusion that there is no final ruling on memory. In some cases forgetting may not only be a choice, but also a given fact. Moreover, despite the exceptional nature of traumatic situations, more than a few authors have identified them in contemporary everyday life. Walter Benjamin's description of the experience of shock is one 
of the earliest and most powerful images of the modern individual, fragmented and unable to react to the stimuli he encounters (Benjamin, 1973).

\section{The response of the new historiography}

In recent years, contemporary historiography has sought to respond to the question posed by Georges Bataille. Historians working in the field of present-day history, and especially oral history, have been concerned with constructing a space within historical narrative in which subjectivity, feelings and human experience can be valued. This concern has translated, on the one hand, into ongoing efforts to uncover the most subtle and camouflaged forms of domination - very often established through the actual social process of constructing memory/ies - and, on the other hand, the salvaging of memories, experiences and existences that have been hidden and silenced. The new historiography gives a voice to those who do not feature in documentary records, enabling group histories to be recovered on a small scale. Through accounts constructed on the basis of the personal trajectory of each individual, which, though partial, contain depth and moral outlines associated with this subjectivity, they seek out elements that have evaded other forms of analysis (Thompson, 1992).

In the text "Memória, esquecimento, silêncio" [Memory, Forgetting, Silence] (1989) Michel Pollak draws our attention to the processes of domination and submission within different versions and memories, pointing out the rift between the dominant official memory and the "underground memories" marked by silence, the unsaid and resentment. This rift may appear not only in relations between a dominating state and civil society, but also in relations between an inclusive society and minority groups. "Forbidden," "unspeakable" or "shameful" memories very often contradict the most legitimate and powerful of all collective memories: national memory.

In this context, the research of Henri Rousso and Alessandro Portelli proves very interesting. Rousso studied the "framing" processes of the French national memory involving concealment and political reconstruction, principally with regard to the Second World War, the Resistance and collaborationism. He shows that both collaboration and the Vichy government were relegated to the margins of the national memory, forgotten and, worse, concealed (Rousso, 1987). 
Portelli, in a text well known to researchers working with oral history, studied the different "layers" to the memory of a massacre carried out by German soldiers in the small Italian city of Civitella. To the Italian government, Civitella was a symbol of resistance to fascism, and the anniversary of the massacre was commemorated with national honours. However, Portelli discovered an underground memory in the statements of local residents that had been hidden and was very different from the official memory. Surviving local residents felt that the massacre was due to the irresponsibility of partisan militants, who had killed some German officers and left the population exposed to Nazi vengeance. This local memory did not fit with the official memory which praised the heroism of the small town and was therefore concealed (Portelli, 1996).

The warning given by the French historian Pierre Ansart (2001) applies perfectly to the studies produced by Rousso and Portelli: "We must consider the rancour, envy, desire for vengeance and phantoms of death." Ansart's aim is to incorporate the "shadowy, disturbing, frequently terrifying" aspects of past experience into historical narrative. Basing his arguments in particular on Nietzsche, Ansart proposes to researchers a history of resentment, a history which takes into account, for example, the experience of humiliation and fear as driving forces behind human action and reaction.

These four authors engage with the political trauma resulting from genocide, dictatorship and tyranny. In our opinion, many important contributions to this theme have come from researchers involved in oral history, women's history and anthropology. We would now like to comment on some of these works - several of which are still in the research and conclusion stages.

The first work we wish to analyse is that of Silvia Salvatici, an Italian researcher who is studying the impact of violence of the Kosovo war through oral statements supplied by immigrants. Two of her texts have been published in the Revista de História Oral: "Memórias de gênero: reflexões sobre a história oral de mulheres" [Gendered Memories: Reflections on Women's Oral History] and "Narrativas de violência no Kosovo do pós-guerra" [Narratives of Violence in Post-war Kosovo] (Salvatici, 2005a e 2005b). In the two works, which complement each other to a significant extent, Salvatici identifies an important issue: the new and revealing focus that is brought to bear on the construction of historical narrative through women's statements. She emphasises the fact that oral history and women's history have developed together and have mutually reinforced each other. Both emerged out of a 
concern to salvage what had not been recorded for history and which, in most cases, relied only on testimony and oral statements to be remembered and understood. Both fields were concerned with rescuing this "voice of the past" researchers of oral history and women's history this was a militant, political concern, and when both fields intersected, history actually encountered something new.

In her empirical research, Salvatici shows us the richness of experiences marked by female subjectivity and gender-based behaviour and stances determined by a war situation. She reproduces the statements of women who had been in concentration camps, worked for the resistance and lived through civil wars, bringing to history a whole aspect of human experience in times of war and domination that had previously been unknown and hidden. Events and experiences involving rape, clandestine childbirth, abortion, care of the sick, protection of children, the hoarding of food, making of clothes or even disguises, and improvised ways of coping with cold and hunger in times of extreme scarcity now enter history. Other statements by women describe the experiences of clandestine love, kisses exchanged across the barricades, hasty marriages, lonely pregnancies, the joy of successful births in precarious circumstances. The romantic side to political activities in times of war is brought to light by oral accounts and statements by women. In short, they reveal a wide range of experiences and ways of confronting war and tyranny that were previously unknown and had not appeared in historical accounts and records, or even in the statements of individuals who had lived through these situations. Most of these statements had been provided by men and were based on male experiences in prisons, concentration camps and resistance groups. The typically female experience of these types of traumatic situations could only be highlighted through a combination of oral history and women's history. Only in this way was it possible for researchers to bring a dimension of human experience and existence to history that had been totally ignored because it was based on a female subjectivity excluded from historical narrative.

Another historian who has raised important questions concerning the relationship between politics and subjectivity is the South African Jonathan Grossman. His text "Violência e silêncio: Reescrevendo o futuro" [Violence and Silence: Rewriting the Future], also published in the Revista de História Oral, brings to light the dramatic consequences of a political process which attempted to ignore and, at certain moments, override the

\footnotetext{
${ }^{7}$ An expression coined by the English historian Paul Thompson, 1992.
} 
subjectivities of the actors involved in the political history of South Africa. Grossman's text analyses the political process of national reconciliation and the rebuilding of the social compact in the country after the apartheid regime ended. He focuses explicitly on the work of the Truth and Reconciliation Commission, whose objective was to repair the damage caused to victims and develop a human rights policy (Grossman, 2000).

Grossman raises an important point: the Commission looked on everyone who had suffered at the hands of the regime - through imprisonment, torture, clandestinity, ill treatment or humiliation - as victims. These people were called upon to make statements and describe before the Commission what they had suffered. Whilst not disagreeing with the importance of this work, Grossman draws attention to the fact that countless people, particularly young people, wanted to make statements to the Commission, but not as victims. They wanted to record their achievements in the struggle, the resistance, the fight. They did not feel they were victims, but rather heroes of combat. Yet there was no place for them; their statements were not wanted or recorded. The Commission was not looking for heroes, but victims. Many of these young people rejected being turned into victims, they did not regard themselves as such and did not want this role in history. However, the Truth and Reconciliation Commission provided no space for them and was not interested in this kind of historical record.

Grossman draws attention to a political process that "places suffering over and above engagement and political resistance": "As the focus is only on pain, people who have lived through the entire experience of survival and resistance end up being reduced simply to victims, and the fact that they also survived and resisted is not taken into account" (2000: 19-20). There was a refusal on the part of these young people to accept the role of victim and a desire to affirm an identity linked to the idea of resistance. This subjectivity, for Grossman, was jettisoned from the post-apartheid political process and this was to fuel powerful currents of resentment in South African society, to the extent of dangerously compromising the success of the political reconciliation process.

We should now like to comment on the relevance of another work - this time from the field of anthropology - which discusses the relationship between subjectivity and politics. The book by Kimberley Theidon, an anthropologist at Harvard University who has studied Peru for many years, is significantly entitled Entre Prójimos: el conflicto armado interno y la política de la reconciliación em el Peru (2004). The book deals with the armed conflict which 
took place in Peru in the 1980s as a result of the political actions of the Sendero Luminoso (Shining Path) extremist group. It is based on fieldwork undertaken in Ayacucho, a region where the Peruvian armed conflict made the greatest number of victims, most of whom were from the indigenous population. Theidon studied seven indigenous communities who had suffered and inflicted suffering. Her starting point was that the inhabitants of the indigenous communities (and sometimes entire communities) felt constrained to ally themselves either with the senderistas or the Armed Forces. It was precisely this characteristic that conferred on the Peruvian armed conflict - at least in the Ayacucho region - the status of a civil war. It set peasants and Indians allied with Sendero Luminoso against peasants and Indians who supported the Armed Forces.

The question that Theidon explored in her extensive fieldwork was that of civil participation in the killings and violence carried out and experienced by the indigenous peasant population: "How did people start killing those closest to them? How did everyday life and subjectivities become militarised and demilitarised?" (Theidon, 2004). This is the question posed in the preface to the book. Theidon specifically explores the question of the construction of subjectivity in times of civil war, the experience of social groups who have been politically abandoned, manipulated by guerrillas and the Armed Forces and involved in violent conflicts with neighbours, relatives and acquaintances. She explores despair and politics. It is interesting to note that the Peruvian armed conflict - the war between the Sendero and the Armed Forces that took place in Ayacucho - has only very recently become the object of historical and social research. Until just a short time ago this subject was an unbreakable taboo. Only now have accounts of this experience emerged and, even so, with great difficulty. Theidon describes the enormous problems she faced in obtaining oral statements about the war. Peasants and Indians did not want to talk - much less be recorded - about this subject. Very recently the subject has also been covered in Peruvian literature, a good example of which is the novel La hora azul by Alonso Cueto, which has already been translated and published in Brazil (2006). Peruvian society is beginning to take various steps towards reviewing the history of the war.

As it is a history that has been stifled and, in various senses, kept a secret, Theidon points out the need to be able to decode various types of language in order to study this theme. From amongst these she identifies the language of the body: it is necessary to understand an experience culturally informed by the body, she tells us. The experience of the peasants and 
Indians in this civil war - physical pain, torture, poverty and hunger - has been marked on the body. In her view, the body is a place of memory, a site in which important historical experiences are inscribed.

The theoretical and methodological question which Theidon discusses in her work is precisely this incorporation of the construction of subjectivity into historical and anthropological studies, although this means more than just valuing subjectivity in historical narrative. She goes further, proposing that subjectivity should be incorporated as a research object and tool. Her aim is to investigate the body of people (her witnesses) - how they register and relate experiences of fear, pain, humiliation and also hope, happiness, relief and pleasure; in other words, all the feelings and emotions experienced during a war.

\section{Conclusion}

This article has focused on various approaches which have made an effective contribution towards constructing the notion we have today of what history, memory and forgetting are. Yet, as the philosopher Edward Casey tells us, whatever memory is, it exceeds the scope of human reason and resists being captured in the structure of intentionality. When we need to produce an exact description of memory, it is as if we found ourselves "adrift in a virtual Sargasso Sea of linguistic confusion and oblivion" (Casey, 1987: 89).

Faced with a range of approaches and political implications, we have aimed to emphasise that the problem for researchers exploring the past is not merely related to the search for knowledge, since it involves political and moral issues. ${ }^{8}$ Michel Foucault's critique of history as a means of arbitrarily establishing origins, continuity or even finality in relation to power has given rise to a broad debate on the relationship between knowledge, morality and power (Foucault, 1977). Countless researchers have been involved in denouncing narratives which, although they reveal past facts and events to present generations, reproduce domination and forms of power. The so-called objectivity and neutrality of approaches which seek to reconstitute the past on the basis of scientific methods and rigorous standards may take shape as new forms of control.

In short, by interweaving several interpretations of history, memory and forgetting we have aimed to show that there are various ways of dealing with the past, all of which involve

\footnotetext{
${ }^{8}$ See Seligmann-Silva, 2000, amongst others.
} 
interests, power and exclusion. The politics of just memory needs to strike a balance between an obsession with the past and attempts to impose forgetting.

Research into what has happened in the past - and the related theoretical and methodological debate - has sought in various ways to respond to the limits of representation. We hope - and are working to this end - that new paths will help us to know ourselves better, in an emancipatory and liberating sense. A history of human beings cannot be created by ignoring either the subjectivity of the human condition or its limits. This being the case, let us not let our knowledge of this subjectivity serve as a means to enable some people to create more efficient ways to control and dominate others - this is the pledge of the researchers we have considered during the course of our discussion.

Translated by Sheena Caldwell

Revised by Teresa Tavares

\section{References}

Ansart, Pierre (2001), "História e memória dos ressentimentos," in Stella Bresciani; Marcia Naxara (eds.), Memória (res)sentimento: indagações sobre uma questão sensível. São Paulo: Editora da Unicamp, 15-36.

Bataille, George (1995), "Concerning the Accounts Given by the Residents of Hiroshima," in C. Caruth (ed.), Trauma: Explorations in Memory. Baltimore: The John Hopkins University Press, 221-235.

Beck, Ulrich; Giddens, Anthony; Lash, Scott (1994), Reflexive Modernization: Politics, Tradition and Aesthetics in the Modern Social Order. Stanford, Ca.: Stanford UP.

Benjamin, Walter (1968), "Thesis on the Philosophy of History," in Hannah Arendt (ed.), Illuminations. New York: Harcourt Brace \& World, 253-264.

Benjamin, Walter (1973), Charles Baudelaire: A Lyric Poet in the Era of High Capitalism. London: NLB.

Casey, Edward S. (1987), Remembering: A Phenomenological Study. Bloomington: Indiana UP.

Cueto, Alonso (2006), A hora azul. Rio de Janeiro: Objetiva.

Davis, Natalie Zemon; Starn, Randolf (1989), "Introduction: Memory and Counter-Memory," Representations, 26, 1-6.

Foucault, Michel (1977), "Nietzsche, Genealogy, History," in M. Foucault, Language, Countermemory, Practice. New York: Cornell UP, 139-164.

Freud, Sigmund (1955), "Beyond the Pleasure Principle," in James Strachey (ed.), The Standard Edition of the Complete Psychological Works of Sigmund Freud. London: Hogarth Press, vol. 18, 3-64 [1920]. 
Friedländer, Saul (1992), Probing the Limits of Representation: Nazism and the 'Final Solution'. Cambridge, Mass.: Harvard UP.

Giddens, Anthony (1990), The Consequences of Modernity. Stanford, Ca.: Stanford UP.

Grossman, Jonathan (2000), "Violência e silêncio: Reescrevendo o futuro," História Oral, Revista da Associação Brasileira de História Oral, 3.

Halbwachs, Maurice (1925), Les cadres sociaux de la mémoire. Paris: Felix Alcan [English translation: On collective memory. Chicago: The University of Chicago Press, 1992].

Halbwachs, Maurice; Alexandre, J.H. (1950), La mémoire collective. Ouvrage posthume publié. Paris: PUF [English translation: The collective memory. New York: Harper \& Row/ Colophon Books, 1980].

Koselleck, Reinhart (1985), Futures Past: On the Semantics of Historical Time. Cambridge, Mass.: MIT Press.

Lash, Scott (1998), "Being After Time: Towards a Politics of Melancholy," in S. Lash; A. Quick; R.H. Roberts, Time and Value. Oxford, UK / Malden, Mass.: Blackwell, 147-161.

McNamara, Robert S. (1996), In Retrospect: The Tragedy and Lessons of Vietnam. New York: Vintage Books.

Middleton, David; Edwards, Derek (1990), Collective Remembering. London: Newbury Park / Ca.: Sage Publications.

Nora, Pierre (1984), Les lieux de mémoire. Paris: Gallimard.

Pollak, Michael (1989), “Memória, esquecimento e silêncio,” Estudos Históricos, 3, 3-15.

Portelli, Alessandro (1996), "O Massacre de Civitella Val di Chiara (Toscana, 29 de junho de 1944): mito e política, luta e senso comum," in Marieta de Moares Ferreira; Janaína Amado (eds.), Usos e abusos da história oral. Rio de Janeiro: Editora Fundação Getúlio Vargas, 103-130.

Ricœur, Paul (2000), La mémoire, I'histoire, l'oubli. Paris: Seuil.

Rousso, Henri (1987), La syndrome de Vichy. Paris: Seuil.

Salvatici, Silvia (2005a), "Memórias de gênero: reflexões sobre a história oral de mulheres," História Oral, Revista da Associação Brasileira de História Oral, 8(1), 29-42.

Salvatici, Silvia. (2005b), "Narrativas de violência no Kosovo do pós-guerra," História Oral, Revista da Associação Brasileira de História Oral, 8(1), 115-127.

Santos, Myrian Sepúlveda dos (1998), "Sobre a autonomia de novas identidades coletivas: Alguns problemas teóricos," Revista Brasileira de Ciências Sociais, 13(38), 151-165.

Seligmann-Silva, Marcio (2000), "A História como Trauma," Catástrofe e Representação: ensaios. São Paulo: Escuta, 73-98.

Scheler, Max; Frings, M. S. (1994), Ressentiment. Milwaukee, Wis.: Marquette University Press.

Taussig, Michael T. (1986), Shamanism, Colonialism, and the Wild Man: A Study in Terror and Healing. Chicago: University of Chicago Press. 
Theidon, Kimberly (2004), Entre Prójimos: el conflicto armado interno y la política de la reconciliación en el Peru. Lima: IEP.

Thompson, Paul (1992), A voz do passado. Rio de Janeiro: Paz e Terra [Portuguese trnaslation of The Voice of the Past. Oxford: OUP, 1978].

White, Hayden (1987), The Content of the Form: Narrative Discourse and Historical Representation. Baltimore: Johns Hopkins UP. 